\title{
Labour Relations Practices in Tea Industry of Assam-With Special Reference to Jorhat District of Assam.
}

\author{
Dr. Horen Goowalla. \\ Associate Professor,Department of Commerce, Mariani College,
}

\begin{abstract}
There is no shadow of doubt about the pivotal role played by Labour Relation practices in bringing about a sense of contentment and pleasure among the workers of an industry. Therefore, an attempt has been made to study the existing Labour Relation Practices in tea industry of Assam. Tea industry is the most important industry in the state of Assam and it is labour intensive. Samples have been drawn from three tea estates belonging to three different types of organizations namely public, private and government ownd.Opinions are sought from the selected samples on important parameters of Labour Relation such as personal policies and practices, wages and salaries, working conditions, union activities, participative schemes, redressal of grievances etc. It was found that though the responses of the workers vary from one tea estates to another. They reflected a strong degree of dissatisfaction on different parameters associated with the practices of labour relation. Therefore, it will not be wrong to opine that tea industry of Assam has long been neglecting the human aspect of the organizations. An attempts has been undertaken to highlights the strong areas where the tea estates would be advised to capitalize on; and to identify problem areas and formulate suitable recommendations to improve the pattern of labour relations in tea estates of Assam.
\end{abstract}

Keyword: personal policies and practices, participative schemes, union activities, wages and salaries, working conditions,

\section{Introduction}

Tea industry is the most important industry in Assam as elsewhere in the country. It is a major industry of Assam. The industry has yielded fame and wealth not only to the state of Assam but also to the nation and in international matters. Leaving apart the other component of the industry let us peep into the human input of the industry giving special emphasis on the workers. There are about eight lakhs workers working in more than one thousand tea estates in Assam. In the very beginning, the planters had to face great difficulties in securing the necessary labour force for the plantation and it became necessary to bring workers from some other parts of the country. A large number of very poor people especially from Orissa, Bihar, Madhya Pradesh and other part of India were brought by the Britishers with fabulous offer to work in the tea gardens in Assam. Since then, the migrated workers have been playing an important role in the development of tea industry of Assam. They are now part and parcel of the industry. In the course of time many of the migrated workers settled down permanently and are contributing towards the economy of Assam.

"The permanent settlement of workers in and around the plantations is mainly because recruitment of workers in the initial stages was family based. Workers were encouraged to migrate to the plantations with their families. This served two purposes. First, the planters wanted cheap labour who would permanently settle in the plantations and this could be achieved by encouraging families to migrate rather than individuals. The entire family male, female and children-worked on the plantation at wages determined by the planters. Secondly, family migration ensured that labour could be reproduced which would ease the problem of further recruitment in the future.

The state of Assam is marked by considerable diversity- geographical, economical, social and political etc. The same is reflected in the tea estates and its workforce. The economic conditions of the tea garden labourers in different parts are far from uniform. Accordingly, the conditions and other amenities vary from estate to estate. It becomes difficult, therefore, to project a clear picture on the basis of studies carried out in a few tea estates.

Table 1.1 Employment of Labour in the Tea Industry of Assam

(Estimated Average Daily Number of labour Employed in Tea Plantation in India)

\begin{tabular}{|l|l|l|l|}
\hline year & ASSAM & NORTH INDIA & ALL INDIA \\
\hline 2000 & $6,02,531$ & $8,73,400$ & $6,19,663$ \\
\hline 2001 & $6,11,063$ & $8,83,450$ & $12,32,150$ \\
\hline 2002 & $6,19,663$ & $8,95,900$ & $12,55,100$ \\
\hline 2003 & $6,19,663$ & $8,96,272$ & $12,56,210$ \\
\hline 2004 & $6,19,663$ & $8,96,717$ & $12,57,610$ \\
\hline 2005 & $6,19,663$ & $8,97,500$ & $12,58,800$ \\
\hline 2006 & $6,19,743$ & $8,98,000$ & $12,59,500$ \\
\hline
\end{tabular}




\section{II. . Labour Relations: A Conceptual Explosion}

Broadly speaking, the term labour relations is composed of two words 'labour' and 'relations'. According to Marshall (1961), labour may be defined as 'any exertion of mind or body undergone partly or wholly with a view to some other than the pleasure derived from the work, while the term relations mean, 'the relationship between the employer and his employees that exists at the work place'. In the words of Cryster (1994), 'the term labour relations has come to mean that part of general labour field which includes the procedure in collective agreements, the servicing of grievance and the conciliation of disputes between the employers and employees, if at all possible, without cessation of work'. It deals with the scientific investigations of the social and psychological inter-relations, establishing a direct relationship between the employer and employee. Labour relations are primarily concerned with the union management relations, techniques of negotiation, collective bargaining, evaluation of labour contracts, discipline, joint consultation, arbitration, conciliation, adjudication and other allied legal matters, strikes and lockouts, labour costs, employment and nonemployment and other terms and conditions of service such as wages, allowances ,bonus, benefit plans, closure, retrenchment, working hours, festival holidays and leave and security of service (Nath and Ghosh).

\section{III. . Review Of Literature}

Since the very purpose of the literature review is to give insight as to how the subject matter is dealt, the researchers have opted to summarize the findings and conclusions drawn from, and recommendations given on the studies made by different researchers in the field of labour relations in India and even in foreign countries.

Haber and Levinson (1956) designed a study of labour relations and productivity in the building trades'. They found that the labour relations pattern in the building trades differs materially from that perfected in other industries. The only suggestion to improve the labour relations in the building trades is the progress in assuring steady employment.

Saxena (1964) in his study entitled, 'Industrial Relations in five Industrial Units of Meerut District' has brought to the forefront the fact that the problems of industrial relations should not be tackled merely on the economic front. These are sociological problems depending for their solution on the mutual trust and confidence among the workers and the employers.

Singh (1966) in his published doctoral thesis entitled, 'Labour Management in Sugar Industry' has observed that there is no initiative on the part of employers willfully (excepting legal obligations) to provide welfare facilities to workers.

Nair (1973) conducted case studies to ascertain the labour management relations in Kerala. He pointed out rich diversity in the pattern and composition of labour management relations that prevail in the state. It shows that Kerala has forged ahead in the matter of evolving a system of labour management relations, which can well be a guide and model for the rest of India.

Das (1983) in his research makes an intensive study of industrial relations in six textile mills of Indore. He found that industrial relations are sociological problems, depending for their solution on the mutual understanding between the operative and managerial staff.

Chand(1989) designed a study of industrial relations in the public sector in Andhra Pradesh. He suggested uniformity in the wage structure of all public sector units in the Andhra Pradesh (to reduce many labour problems).

\subsection{Research Gap}

From the foregoing review of literature it can be understood that though many studies have been conducted on different aspects of labour relations in India and even in foreign countries, a study specifically for labour relations practices in tea industry of Assam is missing in literature. Similarly, no study has made a comparative analysis of degree of satisfaction among the employees of public, private and government owned tea industry of Assam. Moreover, till date, no research has been conducted on any aspects of labour relations in tea estates sampled for this study. Hence, the present study examines empirically the vital issues affecting the relationship between labour and management in selected tea estates of Jorhat Distrct of Assam and suggests measures to make them more effective contributions for the productivity and prosperity of tea estates of Assam.

\subsection{Objectives of the Study}

The present study examines the labour relations practices in tea industry of Assam and aims at making a comparative analysis of labour relations in the tea estates of the state, taking in to account the public, private and government own tea estates of Assam. The important objectives of the study are:

I. To study the labour relations practices in tea estates of Assam;

II. To conducts attitude survey on selected samples, make analysis, and draw conclusions;

III.To highlight the strong areas where the tea estates would be advised to capitalize on; and 
IV. To identify problem areas and formulate suitable recommendations to improve the pattern of labour relations in tea estates of Assam.

\subsection{Research Design}

The tea industry of Assam is divided into two sectors, viz. orgarganised and unorganized (Small growers). The study covering a period of 2000 to 2010 subject to the availability of data refers only to the organized tea estates of Assam, which consists of private, public and government own tea estates of the District. However, one of the best methods of the study would have been to make a survey of all the tea estates of the District But since this is a very large and time consuming project, it was decided to use the case method. Thus, a sample of three tea estates (selecting one from each sector) has been considered as the modest number from the point of view of feasibility of cost and time.

The field investigation is based on a sample of 300 respondents selected through simple random sampling technique with a precision of \pm 5 percent. Out of this, 100 respondents of each sector have been selected to ascertain their reactions towards different labour issues and to locate the problems. While choosing respondents, efforts have been made to ensure that all categories of employees are interviewed. The analysis is based mainly on the responses received from them. The study has been conducted in the following three tea estates:

Public Sector: A Case Study of Hoolung Goorie Tea Estates, Jorhat.

Private Sector: A Case Study of Teok Tea Estates, Jorhat.

Government Own Tea Estates: Dhekiajuli Tea Estates, Jorhat.

\subsection{Research Methodology}

The choice of sampling design and various tools of analysis are based on the specific objectives fixed to the study. Data pertaining to the study are collected both from the primary and secondary sources. Primary data have been collected mostly by direct contact method and prepared questionnaires and schedules to carry out the investigation for this purpose.

All the information based on primary sources has been collected from the personnel departments of the selected tea estates of Assam and through personal interviews with the workers, union leaders, and officers on the basis of pre-structured questionnaires eliciting information on a number of major aspects of labour relations like personnel policies and practices, wages, labour welfare, working conditions, trade unions, strikes, procedure for settlement of disputes, redreesal of respondents' grievances and taking disciplinary action, workers'partipation in management etc.to authenticate the research and arrive at genuine conclusions.

A major chunk of the portion based on the secondary information is obtained from the magazines, newspapers, journals, books, unpublished theses, annual reports of the companies and various other publications of the Government of India and Government of Assam. Finally, all the information and data collected are analyzed and important inferences have been drawn from them.

\subsection{Limitations of the Study}

In the present study, an attempt has been made to cover all important aspects of tea labourers in the tea industry of Assam with the maximum degree of thoroughness. But in this earnest endeavor, various difficulties of a serious nature at all stages of the enquiry have been experienced.

The study, however, brings within its fold almost all vital issues relating to the labour relations in the tea industry of Assam. But it is pertinent to mention that as these are case studies, results and findings presented in it may not strictly apply to the tea industry of Assam as a whole.

An attempt has been made to highlight the empirical part of the work. The respondent's views were taken on a number of common aspects relating to labour relations practices of their respective gardens. In the following pages, an attempt has been made to evaluate their views on these issues:

\section{Respondents' Opinion Towards The Personnel Policies And Practices:} gardens:

The following data reveals the opinion of respondents regarding personnel policies in the sample tea

Table: 1.1 Respondents' Opinion towards the Personnel Policies and Practices in Tea Industry of JorhatDistrict.

\begin{tabular}{|l|l|l|l|l|l|l|l|l|l|l|}
\hline \multirow{2}{*}{ Factors } & \multicolumn{3}{|l|}{ Hoolung Goorie T.E } & \multicolumn{2}{|l|}{ Teok T.E } & \multicolumn{3}{l|}{ Dhekiajuli T.E } \\
\cline { 2 - 10 } & S & D & No & S & D & No & S & D & No \\
\hline $\begin{array}{l}\text { Recruitment } \\
\text { procedure }\end{array}$ & 20 & 70 & 10 & 40 & 60 & -- & -- & 90 & 10 \\
\hline $\begin{array}{l}\text { Selection } \\
\text { procedure }\end{array}$ & 10 & 90 & -- & 50 & 50 & -- & -- & 100 & - \\
\hline $\begin{array}{l}\text { Training } \\
\text { Scheme }\end{array}$ & 10 & 90 & -- & 20 & 80 & -- & -- & 100 & -- \\
\hline
\end{tabular}


Labour Relations Practices in Tea Industry of Assam-With Special Reference to Jorhat District of

\begin{tabular}{|l|l|l|l|l|l|l|l|l|l|}
\hline $\begin{array}{l}\text { Transfer } \\
\text { policy }\end{array}$ & 90 & 10 & -- & 80 & 20 & -- & --- & 100 & -- \\
\hline $\begin{array}{l}\text { Promotion } \\
\text { policy }\end{array}$ & 20 & 80 & --- & 30 & 70 & -- & -- & 100 & -- \\
\hline Total & 150 & 340 & 10 & 220 & 280 & -- & -- & 490 & 10 \\
\hline
\end{tabular}

Source: Questionnaires and personnel interview.

The survey of personnel policies and practices of the sample gardens clearly reveals that the respondents of Dhekiajuli T.E has shown a high degree of dissatisfaction as compared to the respondents of Hoolung goorie T.E and Teok T.E. Out of total, 90\% respondents of Dhekiajuli T.E was dissatisfied with the recruitment procedure. However, in Hoolung Goorie T.E, 70\% respondents was dissatisfied whereas in Teok T.E, The percentage of respondents dissatisfied with the recruitment procedure was $60 \%$. In Hoolung Goorie T.E 20\% of total sample was satisfied with with the recruitment procedure and $40 \%$ respondents was satisfied with the recruitment procedure of Teok tea Estate and 10\% of Hoolung Goorie T.E and Dhekiajuli T.E was given no opinion.

It is analyzed that $90 \%, 70 \%$ and $60 \%$ respondents were dissatisfied and the level of dissatisfaction was very high due to no sound policies and the management did not appoint the right person in right time because they are under the grip of various pressurize groups so that majority of the respondents were not satisfied the recruitment procedure of the sample gardens in the Jorhat District of Assam.

Hundred percentage of the total respondents of Dhekiajuli T.E were dissatisfied with the selection procedure of their company.However, in Hoolung Goorie T.E 70\% respondents were dissatisfied, whereas in Teok T.E, 50\% respondents were dissatisfied with the selection procedure.The percentage of respondents who were satisfied with the selection procedure was just 10\% in Hoolung Goorie T.E, 50\% in Teok t.E and in dhekiajuli T.E, there was no level of satisfaction at all.

\section{Respondents' Towards The Wages And Salaries}

Wages and salaries determine the degree of job satisfaction among the employees. The following table exhibits the opinion of respondents regarding their remunerations.

Table: 1:2 Respondents' Opinion towards the Wages and Salaries

\begin{tabular}{|l|l|l|l|}
\hline Factors & Hoolung Goorie T.E & Teok T.E & Dhekiajuli T.E \\
\hline Satisfied & 70 & 75 & 10 \\
\hline Dissatisfied & 30 & 25 & 80 \\
\hline No Opinion & 00 & 00 & 10 \\
\hline Total & 100 & 100 & 100 \\
\hline
\end{tabular}

When all the three tea gardens were compared on the basis of actual wages and salaries, significant differences were observed. A majority of the respondents in Hoolung Goorie T.E and Teok T.E i.e. 70 percent and 75 percent respectively, were satisfied with the existing wages. However, there is contentment among the respondents of Hoolungoorie T.E and Teok T.E with regard to wages and other financial benefits as compared to Dhekiajuli T.E. The level of discontent was found to be high as 80 percent in Dhekiajuli T.E with regard to the monthly remuneration they get. However, in Hoolungoorie T.E and Teok T.E, only 30 percent and 25 percent respectively were unhappy with their wages.

\section{VI. . Working Conditions}

The environment and conditions under which the employees render their services in a concern is a paramount influencing factor in making the workers complaisant towards their work and life. Therefore, the opinions are sought on this parameter as reflected by the following table :

Table 1.4 Respondents' Opinion towards existing Working Condition

\begin{tabular}{|l|c|c|c|c|c|c|c|c|c|}
\hline \multirow{2}{*}{ Factors } & \multicolumn{3}{|c|}{ Hoolung Goorie T.E } & \multicolumn{3}{|c|}{ Teok T.E } & \multicolumn{3}{c|}{ Dhekiajuli T.E } \\
\cline { 2 - 10 } & $S$ & $D$ & $N O$ & $S$ & $D$ & $N O$ & $S$ & $D$ & $N O$ \\
\hline Apron & 30 & 60 & 10 & 60 & 20 & 20 & 00 & 100 & 00 \\
\hline Umbralla & 25 & 65 & 05 & 50 & 50 & 000 & 00 & 100 & 00 \\
\hline Creche & 25 & 55 & 20 & 30 & 70 & 00 & 00 & 100 & 00 \\
\hline Chappall & 20 & 80 & 00 & 30 & 70 & 00 & 00 & 100 & 00 \\
\hline water & 40 & 50 & 10 & 60 & 40 & 00 & 00 & 100 & 00 \\
\hline
\end{tabular}


Labour Relations Practices in Tea Industry of Assam-With Special Reference to Jorhat District of

\begin{tabular}{|l|c|c|c|c|c|c|c|c|c|}
\hline Lighting & 20 & 60 & 20 & 30 & 70 & 00 & 00 & 100 & 00 \\
\hline sanitation & 30 & 70 & 00 & 40 & 60 & 00 & 00 & 100 & 00 \\
\hline
\end{tabular}

Source: Questionnaire and personal interviews

$\mathrm{S}=$ Satisfied. $\mathrm{D}=$ Dissatisfied. No $=$ No Opinion

The survey highlights that on the whole, the working conditions in Dhekiajuli T.E were quite dissatisfactory since 100 percent of respondents have shown a higher degree of dissatisfaction towards every aspect of working conditions. A close perusal of the data reveals that the working conditions in Hoolung Goorie T.E and Teok T.E were also quite diplorable and a majority of respondents were unhappy against the existing working conditions. Only a small number of respondents in Hoolung Goorie T.E and Teok T.E showed their satisfaction with the working conditions.

\section{Unions Activities And Management's Attitude}

The modern day Trade unions have a greater role to play in not only progressively securing better facilities and amenities to the workers but also in maintaining a good labour relation in the industry. Therefore, the perceptions of the workers are sought about the role and activities of the Trade Unions and responces are shown in the following table

Table: 1.5 Respondents' Opinion towards the Unions Activities and Managements' Attitude towards Unions

\begin{tabular}{|c|c|c|c|c|c|c|c|c|c|}
\hline \multirow{2}{*}{ Factors } & \multicolumn{4}{|l|}{ Hoolung Goorie T.E } & \multicolumn{2}{|l|}{ Teok T.E } & \multicolumn{3}{l|}{ Dhekiajuli T.E } \\
\cline { 2 - 10 } & $S$ & $D$ & $N O$ & $S$ & $D$ & $N O$ & $S$ & $D$ & $N O$ \\
\hline $\begin{array}{c}\text { Unions' } \\
\text { activities }\end{array}$ & 40 & 60 & 00 & 70 & 30 & 00 & 20 & 80 & 00 \\
\hline $\begin{array}{c}\text { Managements' } \\
\text { activities }\end{array}$ & 30 & 60 & 10 & 60 & 40 & 00 & 10 & 90 & 00 \\
\hline
\end{tabular}

S: Satisfaction. D: Dissatisfaction. No: No opinion

It was observed in the survey, that $40 \%$ of the respondent in Hoolungoorie T.E and 70 percent of Teok T.E were satisfied with the activities of the trade unions. However, some respondents were of the view that union leaders of recognized unions in Hoolungoorie T.E and Dhekia juli T.E were under the influence and direct control of the management. The unions neither chalk out any welfare programme nor fight for the rights of respondents, as reflected from the fact that 80 percent of respondents' were not having a good opinion about the activities of unions.

Moreover, it was also reported by 30 percent and 60 percent respondents of Hoolung Goorie T.E and Teok T.E respectively, that the attitude of management was favourable towards union. On the contrary, 90 percent in Dhekiajuli T.E, 60 percent in Hoolung Goorie T.E and 40 percent of Teok T.E alleged that the management does not encourage unions. However, the position with regard to Hoolung Goorie T.E and Dhekia juli T.E was totally different. Generally, the management did not interfere with the legitimate trade union activities. As noted through interviews, 60 percent in Hoolung Goorie T.E and 40 percent in Teok T.E respectively felt that the management of their company possessed a hostile attitude towards their association. Besides, it was observed that no proper record of membership was kept in Hoolung Goorie T.E and Teok T.E by the un-organized unionsof the tea estates. It was also found that workers' participation in trade union activities was significantly low in Dhekia juli T.E and Hoolung Goorie T.E as compared to Teok T.E.

\section{VIII. . Participative Schemes, Redressal Of Grievances And Settlement Of Industrial Disputes:}

Different participative schemes, procedure of redressal of grievances and settlement of industrial dispute are all part and parcel of labour relation practices and all these contribute towards building up a complacent work force. Therefore, opinions of the respondents were sought on these parameters and these are exhibited in the following table:

Table: 1.6 Respondents Opinion towards the Participative Schemes, Procedure of Taking Disciplinary Action,

Redressal of Grievances and Settlement of Industrial Disputes

\begin{tabular}{|l|c|c|c|c|c|c|c|c|c|}
\hline \multirow{2}{*}{ Factors } & \multicolumn{4}{|c|}{ Hoolung Goorie T.E } & \multicolumn{3}{c|}{ Teok T.E } & \multicolumn{3}{c|}{ Dhekiajuli T.E } \\
\cline { 2 - 10 } & $S$ & $D$ & $N O$ & $S$ & $D$ & NO & S & D & NO \\
\hline $\begin{array}{l}\text { Participative } \\
\text { schemes }\end{array}$ & 20 & 70 & 10 & 30 & 70 & 00 & 30 & 70 & 00 \\
\hline Disciplinary & 30 & 70 & 00 & 40 & 50 & 10 & 10 & 90 & 00 \\
\hline
\end{tabular}


Labour Relations Practices in Tea Industry of Assam-With Special Reference to Jorhat District of

\begin{tabular}{|c|c|c|c|c|c|c|c|c|c|}
\hline action & & & & & & & & & \\
\hline $\begin{array}{l}\text { Redressal of } \\
\text { grievances }\end{array}$ & 30 & 70 & 00 & 30 & 70 & 00 & 00 & 100 & 00 \\
\hline $\begin{array}{l}\text { Settlement of } \\
\text { disputes }\end{array}$ & 30 & 70 & 00 & 40 & 50 & 10 & 00 & 100 & 00 \\
\hline
\end{tabular}

Source: Questionnaire and personal interviews

S: Satisfaction. D: Dissatisfaction. No: No opinion

It was observed that a majority of respondents of all the three tea gardens reported that their management does not encourage workers' participation in management, except for a few schemes where there were legal compulsions for worker participation. However, the degree of dissatisfaction in this matter was noted higher in Dhekiajuli T.E .All the 100 percent respondents in Dhekiajuli T.E showed dissatisfaction with the attitude of the management towards activities of the unions. The respondents felt that the management has failed completely in encouraging the workers to involve themselves in different activities of the union and seldom offers opportunities to the workers so that they can participate in the different programmes and policies of management.

The procedure of taking disciplinary action was another aspect on which the respondents' views were sought. It was found that in Teok, only 40 percent of the total respondents appreciated the procedure of taking disciplinary action while the degree of satisfaction was a little lower in Dhekia juli T.E (10\%) and Hoolung Goorie T.E(30\%) respectively. The procedure of redressing grievances was not at all approved by the respondents of Dhekiajuli T.E whereas in Hoolung goorie T.E and Teok T.E 70 percent respondents have shown higher degree of dissatisfaction. The remaining respondents were satisfied with the procedure of redressing grievances. The degree of dissatisfaction among respondents regarding procedure for settlement of disputes was as high as 100 percent in Dhekiajuli T.E, 70 percent in Hoolung Goorie T.E and 50 percent in Teok T.E. On further probe it was found that there was a popular belief among the respondents of Dhekiajuli that the management never solved their problems unless they represented their cases to the conciliation machinery through union leader or resorted to a strike. As most of the respondents are illiterate, they are unable to follow the grievance procedure.

\section{Findings}

1) The workers of the sample tea estates exhibit a high degree of dissatisfaction with regard to recruitment, appointment and selection procedure adopted by the authority and the respondents felt the existence of different pressure groups which had been acting as hindrance in adopting a transparent, suitable and sound recruitment policy.

2) There has been a marked difference in the level of satisfaction of the respondents of the three tea estates chosen for the study with regard to the existing wage system. The Levels of satisfaction in government own tea estates are alarmingly low as compared to the tea estates of Private and Public sector. This is because of mismanagement, bureaucratic red tapism and also failure of the government to pump sufficient capital to these tea estates.

3) The working environment in which the workers are to work reflects a dismal picture as most of the respondents do not feel that the existing working condition is at all up to their satisfaction.

4) The activities of the Trade unions in the sample tea estates are found below the desired level. This is due to the failure on the part of the trade unions in developing a sense of belonging and building trust among the workers by taking a pro-active role.

5) The existing procedure for redressing grievances and settlement of disputes is also not approved and favoured by the workers as they reflected a high degree of dissatisfaction towards these mechanisms.

\section{Conclusion}

The industry in Assam in general and tea industry in particular have long been neglecting the human aspect of the organization. Most of the industries do not even have a Personnel manager. Now the time has come for the tea industry of Assam to realize that in order to produce extra ordinary result, organization will have to depend a great deal on human aspect as this will help in bringing about the much needed competitive edge. This has made 'labour Relation' more significant and meaningful. The tea industry should understand that technology is no longer monopoly nor is the availability of money, but what may be monopoly would be the people associated with the business organization. The competitor of the industry can duplicate the business strategies, but cannot duplicate the people. This, in this context, one shall hope that the tea industry will evolve and develop a mechanism which will help it to enjoy and practice good, sound and timely labour relation activities. 


\section{Acknowledgement:}

At the very outset, I would like to express our deepest sense of gratitude to Mr B.K Gogoi, Principal Mariani College, without whose active support and co-operation, completion of the work within allotted time would not have been possible. I am particularly indebted to Dr A.B.P.Gohain,Prof. P.Sharma,Prof. Lachit Gogoi, respectively for their encouragement and valuable suggestion. I am also thankful miss Sangita Bora for active co-operation. I am also thankful to librarian, Assistant librarian, and other staff members of Mariani college for their sincere co-operation.

\section{Reference:}

[1] A.C.Cryster(1961): labour relations in canada.Toronto;Canada,pp -9.

[2] Alfred Marshal(1961): principles of economics. London: Macmillan \& Co Ltd,Eight Edition,p-54.

[3] D.k.Lal Das (1961): industrial relations in india. New Delhi, S.Chand \& Co Ltd,PP-23.

[4] K.Ramchandran Nair (1973): industrial relations in kerala. New Delhi, Sterling Publishers Pvt Ltd, PP.98-101.

[5] M.P.singh (1966): labour management in sugar industry. Lucknow, educational publishers, PP, 66-79.

[6] R.C.sexana (1964): industrial relations in selected units. New Delhi, planning Commission, PP-1.

[7] S.Nath,P.Ghosh(1973): labour relations in india. New Delhi,Sudha Publications pvt Ltd,pp-79

[8] William Hyber, Harold M.Levinson (1956): labour relations and productivity in the building trades. Barueau of industrial relations, University of Michigan, PP-23-34 